ISSN: 2302-8556

E-Jurnal Akuntansi Universitas Udayana

Vol.23.1. April (2018): 734-760

DOI: https://doi.org/10.24843/EJA.2018.v23.i01.p28

\title{
Intellectual Capital sebagai Pemoderasi Pengaruh Debt to Equity Ratio dan Ukuran Perusahaan pada Profitabilitas
}

\author{
Ni Wayan Rina Winahyu ${ }^{1}$ \\ Ni Putu Sri Harta Mimba ${ }^{2}$
}

${ }^{1}$ Fakultas Ekonomi dan Bisnis Universitas Udayana (Unud), Bali, Indonesia
email: rinawinahyu@ gmail.com/Telp: +62 81999174427
${ }^{2}$ Fakultas Ekonomi dan Bisnis Universitas Udayana (Unud), Bali, Indonesia

\begin{abstract}
ABSTRAK
Peningkatan angka laba salah satunya dengan peningkatan penjualan dengan memanfaatkan modal investasi yang dimiliki perusahaan. Penilaian kinerja keuangan suatu perusahaan pada dasarnya dapat dilakukan dengan menggunakan analisis rasio, salah satunya adalah rasio profitabilitas. Tujuan dalam penelitian ini adalah untuk mengetahui pengaruh debt to equity ratio dan ukuran perusahaan pada profitabilitas perusahaan dengan intellectual capital sebagai variabel pemoderasi. Penelitian ini dilakukan pada perusahaan property dan real estate yang terdaftar di BEI tahun 20142016 yaitu sebanyak 47 perusahaan. Teknik pengambilan sampel yang digunakan adalah non probability sampling dengan teknik purposive sampling. Teknik analisis data yang digunakan adalah uji moderated regression analysis.Berdasarkan hasil analisis ditemukan bahwa DER dan ukuran perusahaan berpengaruh pada profitabilitas perusahaan. selain itu IC memoderasi debt to equity ratio dan ukuran perusahaan pada profitabilitas perusahaan.
\end{abstract}

Kata kunci: DER, ukuran perusahaan, IC, profitabilitas.

\begin{abstract}
The increase in the number of earnings through increased sales with the utilization of investment capital has been done. Assessment of corporate financial performance can basically be done by using ratio analysis, one of which is the profitability ratio. The purpose of this research is to know the effect of debt to equity ratio and firm size on company profitability with intellectual capital as moderating variable.This study was conducted on property and real estate companies listed on the IDX 2014 till 2016 as many as 47 companies. Sampling technique used is non probability sampling with purposive sampling technique. Data analysis technique used is test of moderated regression analysis. Based on the results of the analysis found that DER and firm size affect the profitability of the company. besides the IC moderate the debt to equity ratio and size of the company on the profitability of the company.
\end{abstract}

Keywords: DER, company size, IC, profitability. 


\section{PENDAHULUAN}

Pada umumnya tujuan utama dalam setiap perusahaan adalah mampu memaksimalkan kinerja perusahaan, salah satunya kinerja keuangan perusahaan. Tolok ukur utama untuk kinerja keuangan perusahaan adalah peningkatan angka laba. Peningkatan angka laba dapat dilakukan dengan peningkatan penjualan melalui pemanfaatan modal investasi yang dimiliki perusahaan. Penilaian kinerja bagi manajemen merupakan penilaian terhadap prestasi yang dicapai (Budiasa dkk., 2016). Salah satu cara untuk melakukan penilaian terhadap kinerja keuangan perusahaan yaitu dengan menggunakan analisis rasio. Analisis rasio juga dapat menilai kondisi kesehatan suatu perusahaan. Rasio profitabilitas merupakan salah satu analisis rasio yang dapat digunakan untuk melakukan penilaian atas kinerja keuangan perusahaan. Menurut Kasmir (2012:196), rasio profitabilitas merupakan rasio untuk menilai kemampuan perusahaan dalam mencari laba serta memberikan ukuran tingkat efektivitas manajemen suatu perusahaan. Rasio profitabilitas yang digunakan dalam penelitian ini adalah return on assets (ROA). ROA dapat digunakan untuk mengukur efektivitas perusahaan dalam menghasilkan keuntungan dengan memanfaatkan total aktiva yang dimilikinya.

Perusahaan dalam menjalankan aktivitas operasionalnya membutuhkan dana baik dana yang berasal dari pemilik perusahaan maupun pinjaman, demi kelancaran operasional perusahaan setiap harinya. Trade-off theory merupakan teori yang menjelaskan keseimbangan antara manfaat dan pengorbanan dalam penggunaan utang (Brigham dan Houston,2011:183). Salah satu rasio yang digunakan untuk 
ISSN: 2302-8556

E-Jurnal Akuntansi Universitas Udayana

Vol.23.1. April (2018): 734-760

mengukur tingkat penggunaan utang dalam suatu perusahaan adalah debt to equity ratio (DER). DER mengukur struktur modal suatu perusahaan dengan menilai hutang dengan ekuitas.

Ukuran perusahaan merupakan salah satu variabel yang dapat mempengaruhi profitabilitas perusahaan. Ukuran perusahaan dapat dikategorikan menjadi dua jenis, yaitu perusahaan skala kecil dan perusahaan skala besar (Pratama dan Wiksuana, 2016). Perusahaan besar pada umumnya memiliki fleksibilitas lebih besar dalam memperoleh dana yang diperlukan untuk melaksanakan kesempatan investasi yang lebih menguntungkan. Maka dari itu, kesempatan untuk meningkatkan profitabilitas pada perusahaan besar lebih tinggi bila dibandingkan dengan perusahaan kecil.

Para pelaku bisnis mulai menyadari bahwa kemampuan bersaing perusahaan tidak hanya terletak pada kepemilikan aset fisik maupun aset finansial perusahaan, melainkan pada inovasi, pengelolaan organisasi, dan sumber daya manusia yang dimilikinya. Perusahaan agar mampu tetap bertahan dalam persaingan antar perusahaan, menuntut perusahaan mengubah strategi bisnis perusahaannya. Strategi bisnis yang pada awalnya didasarkan pada tenaga kerja (labor-based business) perlahan diubah menjadi bisnis yang didasarkan pada pengetahuan (knowledge-based business) (Hermawan dan Mardiyanti, 2016). Oleh karena itu, organisasi bisnis semakin fokus dalam mengelola aset pengetahuan (knowledge assets) perusahaan. Pendekatan yang digunakan dalam penilaian dan pengukuran knowledge asset adalah intellectual capital (IC). Menurut Williams (2001) intellectual capital adalah informasi dan pengetahuan yang diaplikasikan dalam pekerjaan untuk mencapai nilai. 
Pengelolaan sumber daya yang baik akan berdampak pada peningkatan kemampuan, keterampilan (skill), dan pengetahuan karyawan. Kemampuan, keterampilam (skill), dan pengetahuan karyawan inilah yang akan memberikan kontribusi pada perusahaan dalam meningkatkan profitabilitas perusahaan.

Populasi yang digunakan dalam penelitian ini adalah perusahaan property dan real estate yang terdaftar di BEI tahun 2014-2016. Perusahaan property dan real estate dipilih dikarenakan sektor tersebut merupakan indikator penting untuk menganalisis kesehatan ekonomi suatu negara. Sektor property dan real estate juga merupakan sektor pertama yang memberi sinyal jatuh atau sedang bangunnya perekonomian suatu negara. Selain alasan tersebut, diambilnya sektor ini sebagai objek penelitian dikarenakan dengan banyaknya masyarakat yang menginvestasikan modalnya dalam sektor property dan real estate mengindikasikan meningkatnya pertumbuhan ekonomi suatu negara.

Investasi di bidang properti pada umumnya bersifat jangka panjang dan akan bertumbuh sejalan dengan pertumbuhan ekonomi. Namun pada kenyataannya, beberapa tahun belakangan ini, pertumbuhan kredit sektor property dan real estate cenderung melambat sehingga mengindikasikan sektor tersebut mengalami kelesuan. Krisis ekonomi tahun 2015 menyebabkan melemahnya nilai tukar rupiah terhadap dolar berimbas kepada menurunnya daya beli masyarakat. Hal tersebut juga diperparah oleh tingkat suku bunga yang tinggi sehingga menyebabkan pengembang (developer) dan masyarakat semakin sulit dalam memperoleh dana. Dengan daya beli masyarakat yang rendah, menyebabkan tingkat penjualan property dan real estate 
ISSN: 2302-8556

E-Jurnal Akuntansi Universitas Udayana

Vol.23.1. April (2018): 734-760

mengalami penurunan yang berdampak pada menurunya laba perusahaan. Hal ini dapat dilihat dari menurunnya laba perusahaan berturut-turut selama tahun 2014-2016 pada beberapa perusahaan property dan real estate.

Penelitian yang dilakukan oleh Lindayani (2016) serta Marusya dan Magantar (2016) menyatakan DER berpengaruh positif terhadap profitabilitas. Sedangkan penelitian yang dilakukan oleh Budiasa dkk. (2016), Desnerita (2015), dan Sari (2014) menunjukkan hasil yang berbeda, yaitu DER berpengaruh negatif dan signifikan terhadap profitabilitas. Untuk variabel ukuran perusahaan, penelitian yang dilakukan oleh Amato dan Wilder (2015) menyatakan bahwa ukuran perusahaan tidak berpengaruh terhadap profitabilitas. Berbeda dengan penelitian yang dilakukan oleh Miyanti dan Putra (2012) memperoleh hasil yaitu ukuran perusahaan berpengaruh negatif terhadap profitabilitas. Selain itu, Kencana (2012) dalam penelitiannya menunjukkan ukuran perusahaan berpengaruh positif terhadap profitabilitas. Untuk variabel IC sendiri, penelitian yang dilakukan oleh Rachmawati (2012); Dwipayani dan Prastiwi (2014); Kartika dan Hatane (2013); Marfuah dan Ulfa (2014) menyatakan bahwa IC berpengaruh positif terhadap profitabilitas. Hasil yang berbeda diperoleh melalui penelitian yang dilakukan oleh Hermawan dan Wahyuadi (2013) serta Andriana (2014) yaitu menyatakan bahwa IC berpengaruh negatif terhadap profitabilitas.

Penelitian tentang profitabilitas memang telah banyak dilakukan sebelumnya. Namun adanya ketidak konsistenan hasil penelitian dari penelitian sebelumnya, menyebabkan peneliti menduga terdapat variabel yang memperkuat atau 
memperlemah hubungan DER dan ukuran perusahaan terhadap profitabilitas yaitu IC. IC yang mampu mempengaruhi profitabilitas suatu perusahaan menyebabkan peneliti menduga bahwa variabel IC sebagai variabel yang mampu memperkuat atau memperlemah pengaruh DER dan ukuran perusahaan pada profitabilitas perusahaan. Berdasarkan latar belakang yang telah dipaparkan sebelumnya sehingga peneliti mengangkat judul “Intellectual Capital sebagai Pemoderasi Pengaruh Debt to Equity Ratio dan Ukuran Perusahaan pada Profitabilitas Perusahaan Property dan Real Estate yang Terdaftar di Bursa Efek Indonesia Tahun 2014-2016”

Berdasarkan uraian latar belakang di atas, maka rumusan masalah dalam penelitian ini adalah: (1) bagaimanakah pengaruh debt to equity ratio pada profitabilitas perusahaan?; (2) bagaimanakah pengaruh ukuran perusahaan pada profitabilitas perusahaan?; (3) bagaimana intellectual capital memoderasi pengaruh debt to equity ratio pada profitabilitas perusahaan?; dan (4) bagaimana intellectual capital memoderasi pengaruh ukuran perusahaan pada profitabilitas perusahaan? Tujuan dalam penelitian ini adalah untuk mengetahui dan memberikan bukti empiris mengenai intellectual capital sebagai pemoderasi pengaruh debt to equity ratio dan ukuran perusahaan pada profitabilitas perusahaan. Berdasarkan tujuan penelitian tersebut, maka peneliti berharap hasil penelitian ini dapat memberikan kegunaan secara teoritis maupun praktis. Kegunaan teoritis penelitian ini adalah diharapkan mampu memberikan informasi, wawasan yang lebih luas, dan dapat menjadi refrensi bagi penelitian selanjutnya serta dapat memberikan bukti secara empiris tentang intellectual capital sebagai pemoderasi pengaruh debt to equity ratio dan ukuran 
ISSN: 2302-8556

perusahaan pada profitabilitas perusahaan. Sedangkan kegunaan praktis penelitian ini diharapkan mampu memberikan kontribusi yang berguna sebagai masukan dan bahan pertimbangan bagi para investor dan perusahaan dalam pengambilan keputusan terkait dengan pengaruh debt to equity ratio dan ukuran perusahaan pada profitabilitas perusahaan dengan intellectual capital sebagai variabel moderasi.

Kajian pustaka dalam penelitian ini adalah Trade-off Theory dan teori sumber daya (Resource Based Theory - RBT). Trade-off theory merupakan teori yang menjelaskan keseimbangan antara manfaat dan pengorbanan dalam penggunaan utang (Brigham dan Houston, 2011:183). Apabila manfaat yang diterima masih lebih besar dibandingkan pengorbanan, maka perusahaan akan menambah jumlah hutang yang akan dimiliki perusahaan. Sebaliknya, apabila pengorbanan dalam menggunakan hutang lebih besar daripada manfaat yang diterima, maka perusahaan tidak menambah jumlah hutang yang akan dimiliki perusahaan.

Teori sumber daya (resource based theory - RBT) berpandangan bahwa perusahaan memperoleh keunggulan kompetitif dan kinerja keuangan yang baik dengan cara memiliki, menguasai, dan memanfaatkan aset-aset strategis yang penting (Wernerfelt, 1984). Menurut teori sumber daya, apabila intellectual capital dapat dikelola dan dikembangkan dengan baik, maka perusahaan secara efisien dalam mengelola aset perusahaan sehingga laba bersih perusahaan akan meningkat dan menghasilkan keunggulan kompetitif bagi perusahaan yang berpengaruh terhadap kinerja perusahaan. Begitu pula dengan ukuran perusahaan. Semakin besar ukuran perusahaan cenderung memiliki sumber daya yang lebih baik dibandingkan dengan 
perusahaan kecil. Sumber daya yang lebih baik akan mampu meningkatkan dan menghasilkan keunggulan kompetitif bagi perusahaan sehingga berpengaruh terhadap kinerja perusahaan.

Profitabilitas merupakan salah satu rasio keuangan yang dapat digunakan untuk menganalisis kinerja keuangan suatu perusahaan. Rasio profitabilitas merupakan rasio untuk menilai kemampuan perusahaan dalam mencari laba serta memberikan ukuran tingkat efektivitas manajemen suatu perusahaan (Kasmir, 2012:196). Debt to equity ratio (DER) merupakan salah satu rasio yang digunakan untuk mengukur struktur modal suatu perusahaan dengan menilai hutang dengan ekuitas. Rasio ini menunjukkan jumlah dana yang disediakan peminjam (kreditur) dibandingkan dengan pemilik perusahaan (Kasmir, 2012: 157). Rasio ini juga mampu memberikan petunjuk umum tentang kelayakan dan risiko keuangan perusahaan. Ukuran perusahaan dapat dilihat dari kapitalisasi pasar, penjualan, dan total aktiva. Variabel ukuran perusahaan diukur dengan logaritma natural (Ln) dari total aset. Total aset dipilih sebagai proksi ukuran perusahaan dengan pertimbangan bahwa nilai aset relatif lebih stabil dibandingkan dengan penjualan dan nilai kapitalisasi pasar. Menurut Williams (2001) intellectual capital adalah informasi dan pengetahuan yang diaplikasikan dalam pekerjaan untuk mencapai nilai. Intellectual capital (IC) merupakan aset utama disamping aset fisik dan finansial. Pulic (1998) mengembangkan suatu pengukuran yang secara tidak langsung dapat mengukur efisiensi nilai tambah terhadap IC perusahaan dan dirancang untuk mengevaluasi dan memonitor efisiensi value added (VA) yang dikenal dengan metode value added 
inttelectual capital (VAIC). Secara sistematis, kerangka konseptual dalam penelitian ini dapat digambarkan sebagai berikut:

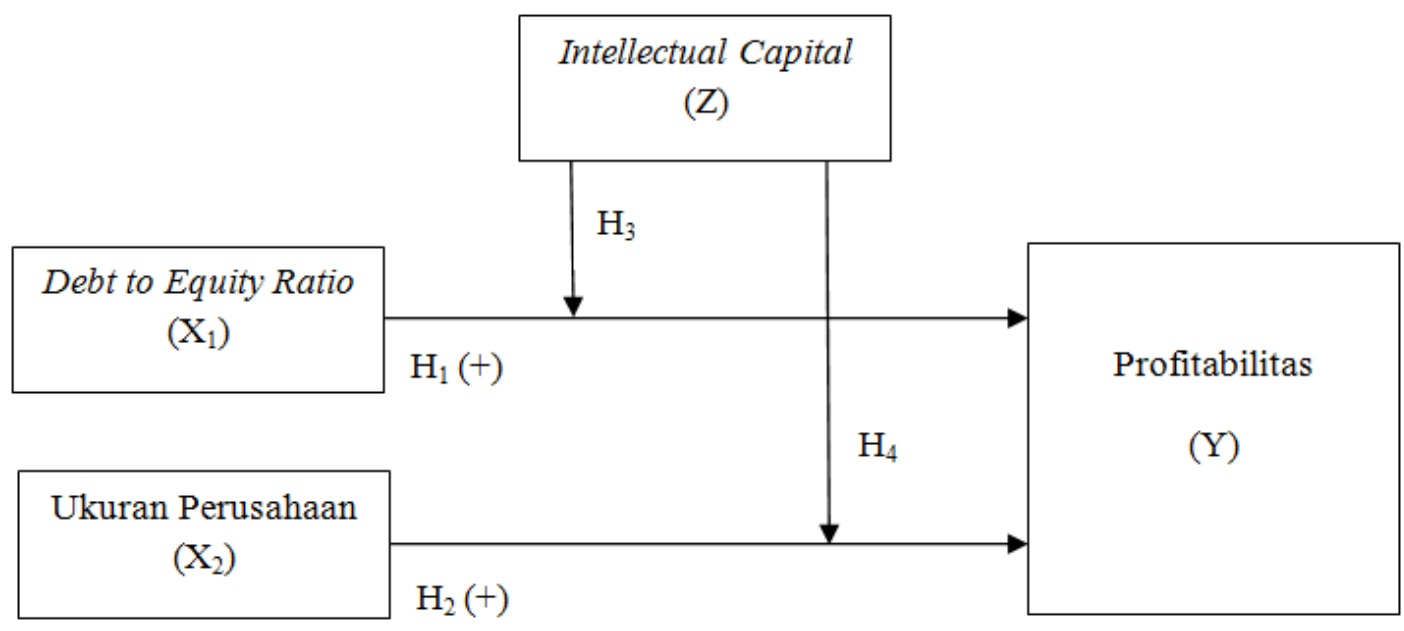

\section{Gambar 1. Kerangka Konseptual}

Debt to equity ratio (DER) merupakan salah satu rasio yang digunakan untuk mengukur struktur modal suatu perusahaan dengan menilai hutang dengan ekuitas. Trade-off theory memprediksi hubungan positif antara struktur modal dengan tingkat profitabilitas perusahaan. Pada perhitungan penghasilan kena pajak, semakin banyak beban bunga yang dimiliki perusahaan akan menyebabkan menurunnya proporsi beban pajak yang dimiliki peursahaan. Hal ini berdampak pada meningkatnya proporsi laba bersih setelah pajak atau tingkat profitabilitasnya akan semakin tinggi (Sartono, 2014:236). Penelitian yang dilakukan oleh Lindayani (2016), Khalid (2011), Kodongo et al. (2014), Marusya dan Magantar (2016) serta Chen dan Yu Chen (2011) yaitu DER berpengaruh positif dan signifikan terhadap profitabilitas. 
Berdasarkan uraian tersebut, maka dapat dirumuskan hipotesis penelitian sebagai berikut:

$\mathrm{H}_{1}$ : Debt to Equity Ratio (DER) berpengaruh positif pada profitabilitas

Ukuran perusahaan dapat dilihat dari kapitalisasi pasar, penjualan, dan total aktiva. Semakin besar ukuran perusahaan, maka kecenderungan pemakaian dana eksternal semakin besar. Perusahaan besar pada umumnya lebih mudah menuju ke pasar modal sehingga menyebabkan perusahaan besar memiliki fleksibilitas lebih besar untuk memperoleh dana yang diperlukan untuk melaksanakan kesempatan investasi yang lebih menguntungkan. Dengan demikian, kesempatan untuk meningkatkan profitabilitas pada perusahaan besar lebih tinggi bila dibandingkan dengan perusahaan kecil. Kencana (2012); Niresh dan Velnampy (2014); Pervan dan Josipa (2012); Pratama dan Wiksuana (2016); serta Salehi dan Nazanin (2012) dalam penelitiannya menyatakan bahwa ukuran perusahaan berpengaruh positif dan signifikan terhadap profitabilitas. Berdasarkan uraian tersebut, maka dapat dirumuskan hipotesis penelitian sebagai berikut:

$\mathrm{H}_{2}$ : Ukuran perusahaan berpengaruh positif pada profitabilitas

DER menunjukkan hubungan antara jumlah pinjaman jangka panjang yang diberikan oleh kreditur dengan jumlah modal sendiri yang diberikan oleh pemilik perusahaan. Rendah atau tingginya rasio DER mengindikasikan kemampuan perusahaan dalam menjamin hutangnya dengan ekuitas yang dimilikinya. Kemampuan perusahan dalam menjamin hutang dengan ekuitas yang dimilikinya tersebut tidak lepas dari adanya keterlibatan karyawan dalam mengelola aset finansial 
ISSN: 2302-8556

E-Jurnal Akuntansi Universitas Udayana

Vol.23.1. April (2018): 734-760

yang dimiliki oleh perusahaan agar mampu tercapainya stabilitas keuangan perusahaan. Penelitian yang dilakukan oleh Rachmawati (2012) menyatakan bahwa IC berpengaruh positif terhadap profitabilitas. Hasil tersebut didukung oleh penelitian yang dilakukan oleh Dwipayani dan Prastiwi (2014) yang menunjukkan bahwa IC berpengaruh positif terhadap profitabilitas. Berdasarkan uraian tersebut, maka dapat dirumuskan hipotesis penelitian sebagai berikut:

$\mathrm{H}_{3}$ : Intellectual Capital memoderasi pengaruh Debt to Equity Ratio pada profitabilitas perusahaan

Perusahaan besar memiliki kecenderungan dalam pemakaian dana eksternal yang semakin besar serta memiliki fleksibilitas yang lebih besar untuk memperoleh dana di pasar modal. Memiliki manajemen yang lebih baik dibandingkan dengan perusahaan kecil, menyebabkan perusahaan besar lebih mudah dalam memperoleh modal untuk operasional perusahaannya yang kemudian berpengaruh terhadap profitabilitas perusahaan. Manajemen yang lebih baik pada perusahaan besar mengindikasikan kemampuan perusahaan dalam mengelola sumber daya perusahaan secara optimal. Penelitian yang dilakukan oleh Kartika dan Hatane (2013) menyatakan bahwa IC berpengaruh positif pada profitabilitas. Hasil yang sama diperoleh dalam penelitian yang dilakukan oleh Marfuah dan Ulfa (2014) yang menunjukkan bahwa IC berpengaruh positif pada profitabilitas. Berdasarkan uraian tersebut, maka dapat dirumuskan hipotesis penelitian sebagai berikut:

$\mathrm{H}_{4}$ : Intellectual Capital memoderasi pengaruh ukuran perusahaan pada profitabilitas perusahaan 


\section{METODE PENELITIAN}

Penelitian ini menggunakan pendekatan kuantitatif asosiatif. Sugiyono (2014:13) menjelaskan bahwa pendekatan kuantitatif merupakan metode penelitian yang digunakan untuk meneliti populasi atau sampel tertentu, pengumpulan data menggunakan instrumen penelitian, analisis data bersifat statistik, dengan tujuan untuk menguji hipotesis yang telah ditetapkan. Sedangkan penelitian asosiatif merupakan penelitian yang bertujuan untuk mengetahui hubungan antara dua variabel atau lebih, yang dapat berfungsi untuk menjelaskan, meramalkan dan mengontrol suatu gejala (Sugiyono, 2016:11). Objek penelitian dalam penelitian ini adalah pengaruh debt to equity ratio dan ukuran perusahaan pada profitabilitas perusahaan dengan intellectual capital sebagai variabel moderasi. Penelitian ini mengambil sampel perusahaan-perusahaan property dan real estate yang terdaftar di Bursa Efek Indonesia (BEI) yang laporan keuangannya dilaporkan secara berkala. Penelitian ini dilakukan dengan mengambil data yang dapat diunduh melalui situs resmi BEI yaitu www.idx.co.id periode 2014-2016.

Variabel adalah suatu atribut atau sifat atau nilai dari orang, obyek atau kegiatan yang mempunyai variasi tertentu yang ditetapkan peneliti untuk dipelajari dan kemudian ditarik kesimpulannya (Sugiyono, 2016:39). Variabel terikat dalam penelitian ini adalah profitabilitas perusahaan. Dalam penelitian ini, rasio profitabilitas diproksikan dengan Return on Assets (ROA). ROA merupakan rasio yang menunjukkan hasil (return) atas jumlah aktiva yang digunakan dalam perusahaan (Kasmir, 2012:202). 


$$
\text { Return on Assets }=\frac{\text { Earning After Tax }(E A T)}{\text { Total asset }} \times 100 \%
$$

Variabel bebas yang digunakan dalam penelitian ini adalah debt to equity ratio sebagai $\mathrm{X}_{1}$ dan ukuran perusahaan sebagai $\mathrm{X}_{2}$. DER berfungsi untuk mengetahui setiap rupiah modal sendiri yang dijadikan jaminan utang (Kasmir, 2012:157). Rasio ini dapat diukur dengan rumus:

$$
\text { Debt to Equity Ratio }=\frac{\text { Total Hutang }}{\text { Total Ekuitas }} \times 100 \%
$$

Ukuran perusahaan adalah ukuran besarnya perusahaan yang dilihat dari jumlah aktiva perusahaan (Sari, 2014). Dalam penelitian ini, ukuran perusahaan diukur dengan menggunakan logaritma natural dari total aset untuk menghindari adanya data yang tidak normal.

Variabel moderasi adalah variabel yang mempengaruhi (memperkuat atau memperlemah) hubungan antara variabel independen dan dependen. Variabel moderasi dalam penelitian ini adalah intellectual capital. Intellectual capital diukur berdasarkan value added yang diciptakan oleh human capital, structural capital, dan costumer capital. Gabungan dari ketiga value added tersebut disebut dengan nama Value Added Intellectual Capital (VAIC). VAIC adalah metode untuk mengukur value added yang diberikan intellectual capital yang dikembangkan oleh Pulic. Pulic (1998) menyatakan bahwa VAIC dapat diukur dengan tahapan sebagai berikut:

a) Value Added (VA)

$$
V A=\text { Output }- \text { Input }
$$

Keterangan: 
Output : total penjualan dan pendapatan lain

Input : beban-beban (selain beban karyawan)

b) Value Added Capital Employed (VACA)

$V A C A=\frac{\text { Value Added }}{\text { Capital Employed }}$

Keterangan:

Value Added (VA) : Selisih antara output dan input

Capital Employed (CE) : Dana yang tersedia (ekuitas)

c) Value Added Human Capital (VAHU)

$V A H U=\frac{\text { Value Added }}{\text { Human Capital }}$

Keterangan:

Value Added (VA) : Selisih antara output dan input

Human Capital (HC) : Beban Karyawan

d) Value Added Structural Capital (STVA)

STVA $=\frac{\text { Structural Capital }}{\text { Value Added }}$

Keterangan:

Structural Capital (SC) : Value Added-Human Capital

Value Added : Selisih antara output dan input

Human Capital : : Beban Karyawan

e) Value Added Intellectual Capital (VAIC)

$V A I C=V A C A+V A H U+S T V A$ 
ISSN: 2302-8556

E-Jurnal Akuntansi Universitas Udayana

Vol.23.1. April (2018): 734-760

Populasi dalam penelitian ini adalah seluruh perusahaan property dan real estate yang terdaftar di Bursa Efek Indonesia selama periode tahun 2014-2016 yang berjumlah 47 perusahaan. Metode pengambilan sampel yang digunakan adalah non probability sampling dengan menggunakan teknik purposive sampling. Metode ini digunakan dengan tujuan untuk terhindar dari adanya bias dari penelitian ini dengan mendapatkan sampel yang sesuai dengan kriteria yang ditentukan. Adapun kriteriakriteria yang digunakan dalam penelitian ini adalah: (1) perusahaan property dan real estate yang menerbitkan laporan keuangan secara berturut-turut selama periode 20142016; (2) perusahaan property dan real estate yang menyediakan data yang mencukupi untuk mengukur debt to equity ratio, ukuran perusahaan, intellectual capital dan profitabilitas perusahaan selama periode 2014-2016; (3) perusahaan property dan real estate yang mengalami keuntungan atau laba positif selama periode 2014-2016. Dengan menggunakan teknik purposive sampling, maka mendapatkan 34 sampel perusahaan. Jenis data yang digunakan dalam penelitian ini adalah data kuantitatif dengan sumber data sekunder.

Teknik analisis data pada penelitian ini adalah Moderated Regression Analysis (MRA) yang diolah dengan bantuan program SPSS. Pengujian dapat dilakukan setelah model dari penelitian ini memenuhi syarat yaitu data harus berdistribusi normal, tidak mengandung multikolinearitas, autokorelasi, dan heteroskedastisitas. Uji asumsi klasik yang dilakukan adalah uji normalitas, uji autokorelasi, uji multikolonieritas, dan uji heterokedastisitas. Pengujian selanjutnya adalah uji statistik deskriptif, setelah itu uji Moderated Regression Analysis (MRA), koefisien 
determinasi $\left(\mathrm{R}^{2}\right)$, uji kelayakan model (Uji F), dan uji hipotesis (Uji t). Model regresi dalam penelitian ini ditunjukkan dengan persamaan sebagai berikut.

$$
Y=\alpha+\beta_{1} X_{1}+\beta_{2} X_{2}+\beta_{3} Z+\beta_{4} X_{1} Z+\beta_{5} X_{2} Z+e
$$

$$
\begin{array}{cl}
\text { Keterangan : } & \\
\text { Y } & =\text { Profitabilitas Perusahaan } \\
\alpha & =\text { Konstanta } \\
\beta_{1}-\beta_{5} & =\text { Koefisien regresi } \\
\mathrm{X}_{1} & =\text { Debt to Equity Ratio } \\
\mathrm{X}_{2} & =\text { Ukuran Perusahaan } \\
\mathrm{Z} & =\text { Intellectual Capital } \\
\mathrm{e} & =\text { Error }
\end{array}
$$

\section{HASIL DAN PEMBAHASAN}

Statistik deskriptif merupakan statistik yang digunakan untuk menganalisa data yang terkumpul dengan cara mendeskripsikan atau menggambarkan data tersebut (Sugiyono, 2014:206). Hasil statistik deskriptif penelitian ini dapat dilihat pada Tabel 1 berikut:

Tabel 1. Hasil Statistik Deskriptif

\begin{tabular}{lcrrrr}
\hline \multicolumn{1}{c}{ Variabel } & N & \multicolumn{1}{c}{ Minimum } & \multicolumn{1}{c}{ Maximum } & \multicolumn{1}{c}{ Mean } & Std. Deviation \\
\hline ROA & 102 & .0008 & .3589 & .0767 & .05628 \\
DER & 102 & .0356 & 1.8337 & .6974 & .45631 \\
SIZE & 102 & 25.8922 & 31.4510 & 29.0873 & 1.33346 \\
IC_Z & 102 & 1.2605 & 43.6568 & 7.1190 & 7.18257 \\
\hline \multicolumn{2}{l}{ Sumber: Data diolah, 2017} & & & &
\end{tabular}

Variabel profitabilitas yang diproksikan dengan return on assets (ROA) hasil uji statistik deskriptif menggambarkan bahwa, nilai ROA terendah sebesar 0,0008 dan nilai ROA tertinggi mencapai 0,3589 . Rata-rata nilai ROA yaitu sebesar 0,0767 dengan standar deviasi sebesar 0,05628 menunjukkan data pada variabel profitabilitas 
ISSN: 2302-8556

E-Jurnal Akuntansi Universitas Udayana

Vol.23.1. April (2018): 734-760

memiliki sebaran yang kecil karena nilai standar deviasi lebih kecil dari nilai rataratanya.

Variabel debt to equity ratio (DER) hasil uji statistik deskriptif menggambarkan bahwa, nilai DER terendah sebesar 0,0356 dan nilai DER tertinggi mencapai 1,8337 Rata-rata DER sebesar 0,6974 dengan standar deviasi sebesar 0,45631 menunjukkan data pada variabel DER memiliki sebaran yang kecil karena nilai standar deviasi lebih kecil dari nilai rata-ratanya. Variabel ukuran perusahaan (SIZE) hasil uji statistik deskriptif menggambarkan bahwa nilai Ln total aset terendah sebesar 25,8922 dan nilai Ln total aset tertinggi mencapai 31,4510. Rata-rata Ln total aset sebesar 29,0873 dengan standar deviasi sebesar 1,33346 menunjukkan data pada variabel ukuran perusahaan memiliki sebaran yang kecil karena nilai standar deviasi lebih kecil dari rata-ratanya.

Variabel intellectual capital (IC) hasil uji statistik deskriptif menggambarkan bahwa, nilai IC terendah sebesar 1,2605 dan nilai IC tertinggi mencapai 43,6568 pada. Rata-rata nilai IC sebesar 7,1190 dengan standar deviasi sebesar 7,18257 menunjukkan data pada variabel IC memiliki sebaran yang cukup besar karena nilai standar deviasi lebih besar dari rata-ratanya. Uji normalitas dilakukan dengan tujuan untuk menguji apakah dalam residual dari model regresi yang dibuat berdistribusi normal ataukah tidak. Uji normalitas dilakukan dengan melakukan uji KomogorovSminarnov. Berdasarkan hasil uji normalitas, dapat dilihat bahwa nilai Asymp. Sig. (2-tailed) yaitu sebesar 0,122 yang lebih besar dari 0,05. Dapat disimpulkan bahwa seluruh data berdistribusi normal. 
Ni Wayan Rina Winahyu dan Ni Putu Sri Harta Mimba. Intellectual...

Uji autokorelasi muncul karena observasi yang berurutan sepanjang waktu berkaitan satu sama lainnya. Dengan menggunakan derajat kepercayaan $\alpha=5 \%$, data pengamatan sebanyak 102, dan 3 variabel independen, maka dapat dilihat dalam tabel Durbin-Watson menghasilkan nilai du sebesar 1,74 dan nilai 4 - du sebesar 2,26. Pada model moderated regression analysis diperoleh nilai durbin-watson sebesar 1,824. Nilai durbin-watson sebesar $1,824>$ du dan $1,824<4-$ du sehingga model regresi yang digunakan dalam penelitian tidak mengandung gejala autokorelasi sehingga lolos uji autokorelasi.

Uji multikolinieritas bertujuan untuk menguji apakah dalam model regresi ditemukan adanya korelasi antara variabel independen. Model regresi yang baik seharusnya tidak terjadi korelasi diantara variabel independen. Nilai cut off yang umum dipakai untuk menunjukkan adanya multikolinearitas adalah nilai tolerance $\leq$ 0,10 atau nilai $\mathrm{VIF} \geq 10$. Berdasarkan hasil uji multikolinearitas, nilai VIF lebih kecil dari 10 dan nilai tolerance lebih besar dari 0,1. Sehingga dapat disimpulkan bahwa antar variabel independen tidak terjadi masalah multikolinearitas.

Uji heteroskedatisitas dilakukan dengan tujuan untuk menguji apakah dalam model regresi terjadi ketidaksamaan variance dari residual satu pengamatan ke pengamatan yang lain. Uji heterokedastisitas dalam penelitian ini dilakukan dengan Uji Glejser. Uji Glejser dilakukan dengan meregresikan variabel bebas terhadap absolut residual. Jika tingkat signifikansi lebih besar dari $\alpha=0,05$, maka model regresi yang dianalisis tidak mengandung gejala heteroskedastisitas. Hasil uji heteroskedastisitas dapat dilihat pada Tabel 2, dibawah ini: 
ISSN: 2302-8556

E-Jurnal Akuntansi Universitas Udayana

Vol.23.1. April (2018): 734-760

Tabel 2.

Hasil Uji Heteroskedastisitas

\begin{tabular}{llll}
\hline Model & Sig. & Keterangan \\
\hline 1 & (Constant) & .178 & \\
DER & .052 & Bebas Heteroskedastisitas \\
SIZE & .070 & Bebas Heteroskedastisitas \\
IC_Z & .232 & Bebas Heteroskedastisitas \\
X1Z & .195 & Bebas Heteroskedastisitas \\
X2Z & .217 & Bebas Heteroskedastisitas \\
\hline
\end{tabular}

Sumber: Data diolah, 2017

Berdasarkan hasil pengujian yang ditunjukkan pada Tabel 5, tingkat signifikansi semua variabel berada diatas 0,05 . Hal ini menunjukkan bahwa model regresi ini bebas dari masalah heteroskedastisitas.

Penelitian ini memakai uji Moderated Regression Analysis (MRA) untuk melihat interaksi intellectual capital dalam memperkuat atau memperlemah pengaruh debt to equity ratio dan ukuran perusahaan pada profitabilitas perusahaan property dan real estate yang terdaftar di Bursa Efek Indonesia. Hasil moderated regression analysis (MRA) dalam penelitian ini dapat dilihat pada Tabel 3 berikut:

\section{Tabel 3.}

\begin{tabular}{|c|c|c|c|c|c|c|}
\hline \multicolumn{7}{|c|}{ Hasil Uji Moderated Regression Analysis } \\
\hline & \multirow[b]{2}{*}{ Model } & \multicolumn{2}{|c|}{$\begin{array}{l}\text { Unstandardized } \\
\text { Coefficients }\end{array}$} & \multirow{2}{*}{$\begin{array}{l}\text { Standardized } \\
\text { Coefficients } \\
\text { Beta }\end{array}$} & \multirow[b]{2}{*}{$\mathbf{T}$} & \multirow[b]{2}{*}{ Sig. } \\
\hline & & B & Std. Error & & & \\
\hline \multirow{6}{*}{1} & (Constant) & -.296 & .102 & & -2.915 & .004 \\
\hline & DER & -.032 & .014 & -.262 & -2.341 & .021 \\
\hline & SIZE & .012 & .004 & .284 & 3.267 & .002 \\
\hline & IC_Z & .071 & .010 & 9.011 & 7.251 & .000 \\
\hline & $\mathrm{X} \overline{1 Z}$ & .006 & .002 & .389 & 3.176 & .002 \\
\hline & $\mathrm{X} 2 \mathrm{Z}$ & -.002 & .000 & -8.576 & -6.630 & .000 \\
\hline & Square $\left(\mathrm{R}^{2}\right)$ & & ,688 & & & \\
\hline & ansi F & & 000 & & & \\
\hline
\end{tabular}

$$
Y=-0,296-0,032 X_{1}+0,012 X_{2}+0,071 X_{3}+0,006 X_{1} Z-0,002 X_{2} Z+e
$$


Berdasarkan Tabel 6, menunjukkan bahwa nilai dari uji $\mathrm{F}$ dalam penelitian ini yaitu sebesar 0,000 dengan signifikansi uji $\mathrm{F}$ sebesar $0,000<0,05$ yang artinya model regresi layak digunakan. Hasil uji koefisien determinasi pada Tabel 6 menunjukkan bahwa nilai Adjusted R Square model sebesar 0,688 artinya sebesar 68,8 persen naik turunnya profitabilitas dipengaruhi oleh debt to equity ratio, ukuran perusahaan, intellectual capital dan sisanya 31,2 persen dijelaskan oleh variabel lain diluar model regresi yang digunakan.

Berdasarkan hasil pengujian pada Tabel 6 menunjukkan variabel debt to equity ratio (DER) memiliki koefisien regresi sebesar -0,032 dengan tingkat signifikan sebesar 0,021 yang lebih kecil dari tingkat signifikansi 0,05. Hal ini menunjukkan bahwa debt to equity ratio berpengaruh pada profitabilitas perusahaan, sehingga $\mathrm{H}_{1}$ diterima. Arah koefisien regresi negatif menunjukkan bahwa semakin tinggi nilai DER maka profitabilitas perusahaan yang diproksikan dengan return on assets (ROA) akan menurun. Hasil ini tidak sesuai dengan trade-off theory yang memprediksi hubungan positif antara DER dengan profitabilitas perusahaan. Dengan nilai DER yang semakin kecil, maka hal tersebut menunjukkan semakin besar kemampuan perusahaan dalam menjamin hutangnya dengan ekuitas yang dimilikinya. Sedangkan semakin tinggi DER, menunjukkan komposisi hutang semakin besar dibandingkan dengan modal sendiri yang berdampak pada semakin besar beban perusahaan terhadap pihak luar (kreditur) dan menunjukkan risiko finansial perusahaan semakin tinggi. Rasio yang tinggi juga menunjukkan proporsi modal sendiri yang rendah untuk membiayai aktiva. Berkurangnya proporsi modal 
ISSN: 2302-8556

E-Jurnal Akuntansi Universitas Udayana

Vol.23.1. April (2018): 734-760

sendiri untuk membiayai aktiva akan berpengaruh terhadap operasional perusahaan sehingga berpengaruh terhadap menurunnya profitabilitas perusahaan.

Berdasarkan hasil pengujian pada Tabel 3 menunjukkan bahwa variabel ukuran perusahaan memiliki koefisien regresi sebesar 0,012 dengan tingkat signifikan sebesar 0,002 yang lebih kecil dari tingkat signifikansi 0,05. Hal ini menunjukkan bahwa ukuran perusahaan berpengaruh pada profitabilitas perusahaan, sehingga $\mathrm{H}_{2}$ diterima. Arah koefisien regresi positif menunjukkan bahwa semakin tinggi ukuran perusahaan maka profitabilitas perusahaan yang diproksikan dengan return on assets (ROA) akan meningkat. Semakin besar ukuran suatu perusahaan, maka kecenderungan pemakaian dana eksternal semakin besar. Perusahaan besar lebih mudah menuju ke pasar modal sehingga perusahaan besar memiliki fleksibilitas lebih besar untuk memperoleh dana yang diperlukan untuk melaksanakan kesempatan investasi yang lebih menguntungkan. Dengan demikian, kesempatan untuk meningkatkan profitabilitas pada perusahaan besar lebih tinggi bila dibandingkan dengan perusahaan kecil.

Berdasarkan hasil pengujian pada Tabel 3 menunjukkan bahwa variabel interaksi debt to equity ratio dengan intellectual capital memiliki koefisien regresi sebesar 0,006 dengan tingkat signifikansi sebesar 0,002 yang lebih kecil dari tingkat signifikansi 0,025. Hal ini menunjukkan bahwa intellectual capital memperkuat pengaruh negatif debt to equity ratio pada profitabiltas perusahaan. Rendah atau tingginya rasio DER mengindikasikan kemampuan perusahaan dalam menjamin hutang dengan ekuitas yang dimilikinya. Hal tersebut tidak lepas dari adanya 
keterlibatan karyawan dalam mengelola keuangan perusahaan. Adanya pengelolaan sumber daya yang baik sehingga berdampak pada peningkatan kemampuan, keterampilan (skill), dan pengetahuan karyawan. Kemampuan, keterampilan (skill), dan pengetahuan karyawan inilah yang akan memberikan kontribusi ke dalam perusahaan dalam peningkatan profitabilitas perusahaan.

Berdasarkan hasil pengujian pada Tabel 3 menunjukkan bahwa variabel interaksi ukuran perusahaan dengan intellectual capital memiliki koefisien regresi sebesar -0,002 dengan tingkat signifikansi sebesar 0,000 yang lebih kecil dari tingkat signifikansi 0,025. Hal ini menunjukkan bahwa intellectual capital memperlemah pengaruh positif ukuran perusahaan pada profitabilitas perusahaan. Semakin besar ukuran perusahaan namun tidak didukung dengan pengelolaan sumber daya manusia yang baik akan mempengaruhi profitabilitas perusahaan. Sebaliknya, meskipun perusahaan kecil namun dalam pengelolaan sumber daya manusianya baik maka akan mampu meningkatkan profitabilitas perusahaan. Meningkatnya profitabilitas perusahaan ini, disebabkan oleh adanya kemampuan karyawan dalam memberikan kontribusi dalam peningkatan jumlah profitabilitas perusahaan.

Implikasi dalam penelitian ini dibagi menjadi dua, yaitu implikasi teoritis dan implikasi praktis. Implikasi teoritis dalam penelitian ini diharapkan dapat memberikan pemahaman yang lebih luas mengenai intellectual capital sebagai pemoderasi pengaruh debt to equity ratio dan ukuran perusahaan pada profitabilitas perusahaan property dan real estate. Penelitian ini menyatakan bahwa debt to equity ratio berpengaruh negatif pada profitabilitas perusahaan property dan real estate. Hal 
ISSN: 2302-8556

E-Jurnal Akuntansi Universitas Udayana

Vol.23.1. April (2018): 734-760

ini mengindikasikan bahwa perusahaan dengan nilai DER yang tinggi akan menyebabkan menurunnya profitabilitas perusahaan karena nilai DER yang tinggi menunjukkan komposisi hutang semakin besar dibandingkan dengan modal sendiri yang berdampak pada semakin besar beban perusahaan terhadap pihak luar (kreditur) dan menunjukkan risiko finansial perusahaan. Selain itu, penelitian ini juga menyatakan bahwa ukuran perusahaan berpengaruh positif pada profitabilitas perusahaan. Hal ini mengindikasikan bahwa dengan semakin besarnya ukuran perusahaan, maka profitabilitas perusahaan akan meningkat karena perusahaan besar memiliki fleksibilitas lebih besar untuk memperoleh dana yang diperlukan untuk melaksanakan kesempatan investasi yang lebih menguntungkan. Sedangkan implikasi praktis dalam penelitian ini diharapkan dapat memberikan kontribusi bagi pihakpihak yang berkepentingan khususnya perusahaan property dan real estate mengenai intellectual capital sebagai pemoderasi pengaruh debt to equity ratio dan ukuran perusahaan pada profitabilitas perusahaan. Penelitian ini mengimplikasikan bahwa pengelolaan sumber daya perusahaan memberikan dampak yang cukup besar pada profitabilitas perusahaan. Pengelolaan sumber daya yang baik akan berdampak pada meningkatnya kemampuan, keterampilan (skill), dan pengetahuan karyawan perusahaan. Kemampuan, keterampilan (skill), dan pengetahuan karyawan inilah yang akan mempengaruhi bagaimana perusahaan dalam mengelola keuangannya sehingga mampu meningkatkan profitabilitas perusahaan. 


\section{SIMPULAN}

Berdasarkan hasil penelitian yang telah diuraikan sebelumnya, adapun kesimpulan yang diperoleh adalah penelitian menunjukkan bahwa debt to equity ratio berpengaruh negatif pada profitabilitas perusahaan. Hal ini berarti semakin besar nilai DER, maka profitabilitas perusahaan semakin menurun. Selain itu hasil penelitian menunjukkan bahwa ukuran perusahaan berpengaruh positif pada profitabilitas perusahaan. Hal ini berarti semakin besar ukuran perusahaan, maka profitabilitas perusahaan semakin meningkat. Hasil penelitian menunjukkan bahwa intellectual capital memperkuat pengaruh negatif debt to equity ratio pada profitabilitas perusahaan. Hal ini dapat disebabkan oleh kemampuan perusahan dalam menjamin hutang dengan ekuitas yang dimilikinya tersebut tidak lepas dari adanya keterlibatan karyawan dalam mengelola keuangan perusahaan. Intellectual capital memperlemah pengaruh positif ukuran perusahaan pada profitabilitas perusahaan yang disebabkan oleh karena meskipun perusahaan kecil, namun dalam pengelolaan sumber daya manusianya baik maka akan mampu meningkatkan profitabilitas perusahaan. Meningkatnya profitabilitas perusahaan ini, disebabkan oleh adanya kemampuan karyawan dalam memberikan kontribusi dalam peningkatan jumlah profitabilitas perusahaan.

Saran yang dapat peneliti usulkan berdasarkan hasil penelitian dan simpulan yang telah diuraikan di atas adalah bagi manajemen perusahaan, dengan mempertimbangkan pengaruh debt to equity ratio, ukuran perusahaan, dan intellectual capital agar dapat mengevaluasi faktor-faktor tersebut menjadi 
ISSN: 2302-8556

E-Jurnal Akuntansi Universitas Udayana

Vol.23.1. April (2018): 734-760

pertimbangan dalam meningkatkan profitabilitas perusahaan karena investor akan lebih berminat untuk berinvestasi di perusahaan dengan profitabilitas perusahaan yang tinggi. Sedangkan bagi penelitian selanjutnya, disarankan untuk melakukan perluasan penelitian. Perluasan penelitian yang dimaksud adalah untuk melakukan penelitian pada sektor lain yang terdaftar di Bursa Efek Indonesia selain sektor property dan real estate serta menggunakan tahun pengamatan yang lebih terbaru. Selain itu, dikarenakan dalam penelitian ini memperoleh hasil intellectual capital sebagai variabel pemoderasi semu, untuk penelitian selanjutnya disarankan untuk melakukan penelitian yang menggunakan pemoderasi lain yang mampu memoderasi debt to equity ratio dan ukuran perusahaan pada profitabilitas secara murni.

\section{REFERENSI}

Amato, Louis dan Ronald P. Wilder. 2015. The Effects of Firm Size on Profit Rates in U.S. Manufacturing. Southern Economic Journal University of North Carolina. 52(1), hal:181-190

Andriana, Denny. 2014. Pengaruh Intellectual Capital terhadap Kinerja Keuangan Perusahaan. Jurnal Riset Akuntansi dan Keuangan Universitas Pendidikan Indonesia. 2(1), hal: 251-260

Barney, J. 1991. Firm Resource and Sustained Competitive Advantage. Journal of Management. 17(1), hal: 99-120

Brigham, Eugene F dan Joel F. Houston. 2011. Dasar-dasar Manajemen Keuangan, Edisi 11. Jakarta: Salemba Empat

Budiasa, I. K., I. B. A. Purbawangsa, dan H. Rahyuda. 2016. Pengaruh Risiko Usaha dan Struktur Modal Terhadap Pertumbuhan Aset serta Profitabilitas pada Lembaga Perkreditan Deda di Kabupaten Badung. Journal Ekonomi dan Bisnis Universitas Udayana. 5(7), hal: 1919-1952

Chen, L. Ju dan S. Yu Chen. 2011. The Influence of Profitability on Firm Value with Capital Structure as the Mediator and Firm Size and Industry as Moderators. Investment Management and Financial Innovation. 8(3) 
Desnerita, Amdani dan. 2015. Pengaruh Struktur Modal dan Working Capital Turnover terhadap Profitabilitas (Studi Empiris pada Pembayar Pajak Perusahaan yang Diperiksa oleh KPP Madya Jakarta Pusat). Jurnal Akuntansi Universitas Persada Indonesia. 19(3), hal: 398:419

Dwipayani, C. C. dan A. Prastiwi. 2014. Pengaruh Intellectual Capital terhadap Profitabilitas dan Kinerja Pasar. Journal of Accounting Universitas Diponegoro. 3(3), hal: 1

Hermawan, S. dan U. I. Mardiyanti. 2016. Intellectual Capital dan Kinerja Keuangan Perusahaan Manufaktur High IC Intensive. Jurnal Manajemen dan Bisnis Universitas Muhammadiyah Sidoarjo. 1(1), hal: 70-78

Hermawan, S. dan M. B. Wahyuaji. 2013. Analisis Pengaruh Intellectual Capital terhadap Kemampulabaan Perusahaan Manufaktur Consumer Goods di Bursa Efek Indonesia. Call for Paper Fakultas Ekonomi dan Bisnis Universitas Muhammadiyah Sidoarjo

Kasmir. 2012. Analisis Laporan Keuangan. Jakarta: PT. RajaGrafindo Persada

Kartika, M. Dan S. E. Hatane. 2013. Pengaruh Intellectual Capital pada Profitabilitas Perusahaan Perbankan yang Terdaftar di Bursa Efek Indonesia pada Tahun 2007-2011. Business Accounting Review. 1(2)

Kencana Manuaba, I. B. P. Adi. 2012. Pengaruh Capital Adequacy Ratio, Non Performing Loan, Ukuran Perusahaan, dan Struktur Kepemilikan terhadap Profitabilitas Bank yang Terdaftar di BEI Tahun 2008-2011. Jurnal Akuntansi Universitas Udayana. 1(1)

Khalid, Shah. 2011. Financial Reforms and Dynamics of Capital Structure Choice: A Case of Publically Listed Firms of Pakistan. Journal of Management Research. 3(1), hal: 1-16

Kodongo, M., Leonard M. dan M. T. Mokoteli. 2014. Capital Structure, Profitability and Firm Value: Panel Evidence of Listed Firms in Kenya. Munich Personal RePEc Archive

Lindayani, N. W. dan S. K. Sutrisna Dewi. 2016. Dampak Struktur Modal dan Inflasi terhadap Profitabilitas dan Return Saham Perusahaan Keuangan Sektor Perbankan. E-Jurnal Manajemen Universitas Udayana. 5(8), hal: 5274-5303

Marfuah dan Maricha Ulfa. 2014. Pengaruh Intellectual Capital terhadap Profitabilitas, Produktivitas, dan Pertumbuhan Perusahaan Perbankan. Jurnal Ekonomi dan Bisnis Islam. 9(1) 
ISSN: 2302-8556

E-Jurnal Akuntansi Universitas Udayana

Vol.23.1. April (2018): 734-760

Marusya, P. dan M. Magantar. 2016. Pengaruh Struktur Modal terhadap Profitabilitas pada Perusahaan Tobacco Manufacturers yang Terdaftar di Bursa Efek Indonesia (BEI) Periode 2008-2015. Jurnal Berkala Ilmiah Efisiensi. 16(3)

Miyanti, G. A. D. Akua dan I. W. Putra. 2012. Pengaruh Tingkat Perputaran Kas, Loan to Deposit Ratio, Tingkat Pertumbuhan Jumlah Nasabah, Spread Management, dan Ukuran Perusahaan terhadap Profitabilitas Koperasi Simpan Pinjam. Jurnal Akuntansi Universitas Udayana. 1(1)

Niresh, J. A. dan Velnampy. 2014. Firm Size and Profitability: A Study of Listed Manufacturing Firm in Sri Lanka. International Journal of Business and Management. 9(4), hal: 57-64

Pervan, M dan Josipa Visic. 2012. Influence of Firm Size on Its Business Success. Croatian Operational Research Review (CRORR). 3, hal: $231-223$

Pratama, I. G. B. dan I. G. B. Wiksuana. 2016. Pengaruh Ukuran Perusahaan dan Leverage Terhadap Nilai Perusahaan dengan Profitabilitas sebagai Variabel Mediasi. Jurnal Manajemen Universitas Udayana. 5(2), hal:1338-1367

Pulic, A. 1998. Measuring the Performance of Intellectual Potential in Knowledge Economy. Paper Presented at the $2^{\text {nd }}$ McMaster Word Congress on Measuring and Managing Intellectual Capital by the Austrian Team for Intellectual Potential

Rachmawati, D. A. Dwi. 2012. Pengaruh Intellectual Capital terhadap Return On Assets Perbankan. Jurnal Nominal Akuntansi. 1(1)

Salehi, M dan Nazanin B. M. 2012. A Study of the Roles of Firm and Country on Specific Determinates in Capital Structure: Iranian Evidence. International Management Review. 8(2), hal: 51-85

Sari, Ni Made Vironika. 2014. Pengaruh Debt to Equity Ratio, Firm Size, Inventory Turnover dan Assets Turnover pada Profitabilitas (Studi Empiris pada Perusahaan Wholesale and Retail Trade yang Terdaftar di Bursa Efek Indonesia). Skripsi Fakultas Ekonomi dan Bisnis Universitas Udayana

Sartono, R. Agus. 2014. Manajemen Keuangan: Teori dan Aplikasi. Yogyakarta: BPFE

Sugiyono. 2014. Metode Penelitian Bisnis. Bandung: CV. Alfabeta

Williams, S. M. 2001. Is Intellectual Capital Performance and Disclosure Practices Related?. Journal of Intellectual Capital. 2(3), hal: 192-203. 